\title{
Intraosseous cavernous hemangioma: presentation of a clinical case
}

\author{
Alejandra Arévalo Sáenz ${ }^{1,2^{*}}$ (D) Natalia Frade Porto ${ }^{1}$ and Manuel Pedrosa Sánchez ${ }^{1}$
}

\begin{abstract}
Background: Cavernous hemangiomas are benign tumors that exceptionally affect the cranial bones. The first description of this type of tumor was in 1845 by Toynbee. A review of the literature reveals less than 100 published cases and a growing trend every year. Total surgical excision is the treatment of choice, and the prognosis after complete excision is excellent, with a recurrence usually rare.

Case presentation: We present the case of a 57-year-old patient with a painless tumor of the left frontal bone, of slow growth and osteolytic characteristics from the neuro-radiological point of view. The lesion was excised en bloc by craniectomy, followed by cranioplasty. The anatomopathological diagnosis was intraosseous cavernous hemangioma.

Conclusions: Despite its low frequency, the diagnosis of intraosseous cavernous hemangioma should be considered in the presence of a slow-growing cranial tumor, with solid and painless characteristics, and its osteolytic nature confirmed by radiology. The treatment of choice consists in the complete resection of the lesion.
\end{abstract}

Keywords: Skull base, Craniectomy, Intraosseous cavernous hemangioma, Osteolithic, Benign tumor

\section{Background}

Primary intraosseous cavernous hemangiomas (PICHs) are a rare and infrequent tumor representing 0.7 to $1.0 \%$ of all bone tumors [1]. PICHs are usually found in the spine and rarely appear in the vault cranial, being $0.2 \%$ of cranial bone tumors [2]. The first description of this type of tumors was in 1845 by Toynbee. A review of the literature reveals about 100 published cases and a growing trend every year (Table 1) [3-77]. These tumors are seen mostly in middle age, with a peak around the fourth decade and a male/female ratio that ranges between 3:1 and 2:1 [2].

\section{Case report}

We are dealing with a 57-year-old patient, with no history of interest, referred to our Service for surgical assessment. It had presented, for 4.5 years, a small tumor in the left front region of $1.5 \mathrm{~cm}$ in diameter, which had slowly increased in size (Fig. 1c, d). During the examination, a mass of solid and hard consistency, painless and adhered to deep planes, was palpated under a

\footnotetext{
* Correspondence: praimale@hotmail.com

${ }^{1}$ Neurosurgery Service of the University Hospital of La Princesa, C/ Diego de León 62, 28006 Madrid, Spain

${ }^{2}$ Division of Neurosurgery, University Hospital La Princesa, C/ Diego de León 62, 28006 Madrid, Spain
}

and the CT (Fig. 1d) showed a left frontal intraosseous lesion with osteolytic characteristics with moderate aggressiveness. The radiological differential diagnosis included bone metastasis or plasmacytoma. The systemic studies of tumor tracking (blood count, hematological smear, tumor markers, proteinogram, and cervical-thoraco-abdominal CT) were negative. The percutaneous puncture with fine needle of the tumor was inconclusive for the diagnosis; only blood fragments were obtained. Finally, it was decided to surgically intervene the patient based on the clinical progression of the lesion, with its esthetic implications, as well as to obtain a definitive histological diagnosis. During the surgery, a bone-dependent tumor was identified, with multiple dilated vascular channels in its center, which expanded the external table. To avoid manipulation of the lesion, it was decided to include it in a piece of craniectomy with a circumferential margin of $1 \mathrm{~cm}$ of the seemingly healthy bone. The resulting bone defect was reconstructed by means of a cylindrical metametacrylate plasty, which was fixed to the surrounding bone with titanium miniplates. The postoperative period was uneventful. The definitive anatomopathological diagnosis was intraosseous cavernous hemangioma. 
Table 1 Review of the literature from 1845 to 2016 of the published cases of intraosseous hemangiomas

\begin{tabular}{|c|c|c|c|c|c|c|c|}
\hline Frontal & & & Temporal & Occipital & Parietal & Skull base & Otros \\
\hline Pilcher (1894) [3] & $\begin{array}{l}\text { Relf et al. } \\
\text { (1991) [17], ×2 }\end{array}$ & $\begin{array}{l}\text { Carrasco et al. } \\
\text { (2009) [30] }\end{array}$ & $\begin{array}{l}\text { Sargent et al. } \\
\text { (1965) [38] }\end{array}$ & $\begin{array}{l}\text { Peterson et al. } \\
\text { (1992) [2] }\end{array}$ & $\begin{array}{l}\text { Toynbee et al. } \\
\text { (1845) [54] }\end{array}$ & $\begin{array}{l}\text { Jackson et al. } \\
\text { (1980) [64] }\end{array}$ & $\begin{array}{l}\text { Chaterji et al. } \\
\text { (1969) [66] }\end{array}$ \\
\hline Wyke (1949) [4] & $\begin{array}{l}\text { Peterson et al. } \\
\text { (1992) [2] }\end{array}$ & $\begin{array}{l}\text { Roel et al. } \\
\text { (2012) [31] }\end{array}$ & $\begin{array}{l}\text { Mangham et al. } \\
(1981)[39] \times 3\end{array}$ & $\begin{array}{l}\text { Cervoni et al. } \\
\text { (1995) [18] }\end{array}$ & $\begin{array}{l}\text { Kumar et al. } \\
\text { (1993) [55] }\end{array}$ & $\begin{array}{l}\text { Glasscock et al. } \\
\text { (1984) [40] }\end{array}$ & $\begin{array}{l}\text { Schofield } \\
\text { (1950) [67] }\end{array}$ \\
\hline $\begin{array}{l}\text { Gupta et al. } \\
\text { (1975) [5] }\end{array}$ & $\begin{array}{l}\text { Cervoni et al. } \\
(1995)[18], \times 2\end{array}$ & $\begin{array}{l}\text { Park et al. } \\
\text { (2013) [1] }\end{array}$ & $\begin{array}{l}\text { Glasscock et al. } \\
\text { (1984) [40] }\end{array}$ & $\begin{array}{l}\text { Corr (2000) } \\
{[48]}\end{array}$ & $\begin{array}{l}\text { Yoshida et al. } \\
\text { (1999) [56] }\end{array}$ & $\begin{array}{l}\text { Mazzoni et al. } \\
\text { (1988) [42] }\end{array}$ & $\begin{array}{l}\text { Dickins (1978) } \\
\text { [68] }\end{array}$ \\
\hline $\begin{array}{l}\text { Mclntyre et al. } \\
\text { (1997) [6] }\end{array}$ & $\begin{array}{l}\text { Pastore et al. } \\
\text { (1999) [19] }\end{array}$ & $\begin{array}{l}\text { Xu et al. } \\
\text { (2013) [32] }\end{array}$ & $\begin{array}{l}\text { Suss et al. } \\
\text { (1984) [41] }\end{array}$ & $\begin{array}{l}\text { García-Marín } \\
\text { et al. (2001) [49] }\end{array}$ & $\begin{array}{l}\text { Heckl et al. } \\
\text { (2002) [22] }\end{array}$ & $\begin{array}{l}\text { Bottrill and } \\
\text { Poe (1995) [65] }\end{array}$ & $\begin{array}{l}\text { Inoue et al. } \\
\text { (1982) [69] }\end{array}$ \\
\hline $\begin{array}{l}\text { Gross and } \\
\text { Roth (1978) [7] }\end{array}$ & $\begin{array}{l}\text { Sharma et al. } \\
\text { (1999) [20] }\end{array}$ & $\begin{array}{l}\text { Uemura et al. } \\
\text { (2014) [33], ×2 }\end{array}$ & $\begin{array}{l}\text { Mazzoni et al. } \\
\text { (1988) [42] }\end{array}$ & $\begin{array}{l}\text { Khanam et al. } \\
\text { (2001) [50] }\end{array}$ & $\begin{array}{l}\text { Ajja (2005) } \\
{[57]}\end{array}$ & $\begin{array}{l}\text { Khanam et al. } \\
\text { (2001) [50] }\end{array}$ & $\begin{array}{l}\text { Suss et al. } \\
\text { (1984) [41] }\end{array}$ \\
\hline $\begin{array}{l}\text { Fouad et al. } \\
(1979)[8], \times 2\end{array}$ & $\begin{array}{l}\text { Suzuki et al. } \\
\text { (2001) [21] }\end{array}$ & $\begin{array}{l}\text { Murrone et al. } \\
\text { (2014) [34] }\end{array}$ & $\begin{array}{l}\text { Buchanan et al. } \\
\text { (1992) [43] }\end{array}$ & $\begin{array}{l}\text { Heckl et al. } \\
\text { (2002) [22] }\end{array}$ & $\begin{array}{l}\text { Paradowski et al. } \\
\text { (2007) [58] }\end{array}$ & & $\begin{array}{l}\text { Tashiro et al. } \\
\text { (1991) [70] }\end{array}$ \\
\hline $\begin{array}{l}\text { Shinno et al. } \\
\text { (1986) [9] }\end{array}$ & $\begin{array}{l}\text { Heckl et al. } \\
\text { (2002) [22] }\end{array}$ & $\begin{array}{l}\text { Chun et al. } \\
\text { (2015) [35] }\end{array}$ & $\begin{array}{l}\text { Fierek et al. } \\
\text { (2004) [44] }\end{array}$ & $\begin{array}{l}\text { Buhl et al. } \\
\text { (2007) [26] }\end{array}$ & $\begin{array}{l}\text { Naama et al. } \\
\text { (2008) [28] }\end{array}$ & & $\begin{array}{l}\text { Slaba et al. } \\
\text { (1999) [71] }\end{array}$ \\
\hline $\begin{array}{l}\text { Hook et al. } \\
\text { (1987) [10] }\end{array}$ & $\begin{array}{l}\text { Pottelbergh } \\
\text { et al. (2004) [23] }\end{array}$ & $\begin{array}{l}\text { Hsiao et al. } \\
\text { (2015) [36] }\end{array}$ & $\begin{array}{l}\text { Sasagawa et al. } \\
\text { (2009) [29] }\end{array}$ & $\begin{array}{l}\text { Gibson and } \\
\text { Prayson (2007) [51] }\end{array}$ & $\begin{array}{l}\text { Sasagawa et al. } \\
(2009)[29] \times 2\end{array}$ & & $\begin{array}{l}\text { Moore et al. } \\
\text { (2001) [72] }\end{array}$ \\
\hline $\begin{array}{l}\text { Zucker et al. } \\
\text { (1989) [11] }\end{array}$ & $\begin{array}{l}\text { Politi et al. } \\
\text { (2005) [24] }\end{array}$ & $\begin{array}{l}\text { Yi Yang } \\
\text { (2016) [37] }\end{array}$ & $\begin{array}{l}\text { Silva et al. } \\
\text { (2013) [45] }\end{array}$ & $\begin{array}{l}\text { Baltazar et al. } \\
\text { (2008) [52] }\end{array}$ & $\begin{array}{l}\text { Rumana et al. } \\
\text { (2013) [59] }\end{array}$ & & $\begin{array}{l}\text { Liu et al. } \\
\text { (2003) [73] }\end{array}$ \\
\hline $\begin{array}{l}\text { Hoffmann et al. } \\
\text { (1990) [12] }\end{array}$ & $\begin{array}{l}\text { Cheng et al. } \\
\text { (2006) [25] }\end{array}$ & & $\begin{array}{l}\text { Yang et al. } \\
\text { (2014) [46] }\end{array}$ & $\begin{array}{l}\text { Nair et al. } \\
\text { (2011) [53] }\end{array}$ & $\begin{array}{l}\text { Atci et al. } \\
\text { (2013) [60] }\end{array}$ & & $\begin{array}{l}\text { Jeong and Rhee } \\
\text { (2006) [74] }\end{array}$ \\
\hline $\begin{array}{l}\text { Hornig et al. } \\
(1990)[13], \times 2\end{array}$ & $\begin{array}{l}\text { Buhl et al. } \\
\text { (2007) [26] }\end{array}$ & & $\begin{array}{l}\text { Yetiser et al. } \\
\text { (2014) [47] }\end{array}$ & & $\begin{array}{l}\text { Hsiao et al. } \\
\text { (2015) [36] }\end{array}$ & & $\begin{array}{l}\text { Salunke et al. } \\
\text { (2010) [53] }\end{array}$ \\
\hline $\begin{array}{l}\text { Sinnreich } \\
\text { (1990) [14] }\end{array}$ & $\begin{array}{l}\text { Nasser et al. } \\
\text { (2007) [27] }\end{array}$ & & & & $\begin{array}{l}\text { Kilani et al. } \\
\text { (2015) [61] }\end{array}$ & & $\begin{array}{l}\text { Moravan et al. } \\
\text { (2011) [76] }\end{array}$ \\
\hline $\begin{array}{l}\text { Aurora et al. } \\
\text { (1991) [15] }\end{array}$ & $\begin{array}{l}\text { Naama et al. } \\
(2008) \text { [28] ×2 }\end{array}$ & & & & $\begin{array}{l}\text { Sarmast et al. } \\
\text { (2016) [62] }\end{array}$ & & $\begin{array}{l}\text { Yu et al. } \\
\text { (2014) [77] }\end{array}$ \\
\hline $\begin{array}{l}\text { Faerber and } \\
\text { Hiatt (1991) [16] }\end{array}$ & $\begin{array}{l}\text { Sasagawa et al. } \\
\text { (2009) [29] }\end{array}$ & & & & $\begin{array}{l}\text { Brichacek et al. } \\
\text { (2018) [63] }\end{array}$ & & \\
\hline
\end{tabular}

This table shows all the cases published in the literature since 1846, making a difference between locations. The most frequent are the frontal ones, as our case. Other sites indicate the case where the lesion was located in sphenoid, zygomatic, ethmoid, clivus, orbital arch, etc. $\times 2$ or $\times 3$ refers to the number of cases published by the author

\section{Discussion}

The first case of cranial cavernous hemangioma was described by Toynbee in 1845 [54]. Since then, most of the publications in the scientific literature have been presented in a single clinical case format, with the exception of two reviews of extensive casuistry that constitute the main references on this entity [22]. PICHs of the skull are rare benign vascular tumors, accounting for about $0.2 \%$ of all tumors and $10 \%$ of benign tumors of the skull [59]. They occur most frequently in the spine and rarely in the skull. Of the 93 cases of cranial PICH reported in the literature from 1845 to $2015,44.1 \%$ were located in the frontal bone, $12.9 \%$ in the temporal bone, $11.8 \%$ occurred in the occipital bone, $12,9 \%$ in the parietal, and $5.4 \%$ in the cranial fossa; fewer cases have been reported in sphenoid, zygomatic, ethmoid, clivus, and orbital, etc. [37]. In the review carried out by Wyke, this distribution is supported [19].

They are usually unique lesions, although cases of multiple cranial cavernomas have been described [28]. They usually have a size at the time of diagnosis that ranges between 15 and $25 \mathrm{~mm}$, although lesions of up to
$8 \mathrm{~cm}$ diameter have been described [78]. Its origin is in the vessels of the diploic space, and their blood supplies are branches of the external carotid artery. The middle and superficial temporal arteries are the main sources of blood supply. Within the lesion, the capillaries are widely dilated and separated by fibrous tissue [77]. Its pathogenesis remains unknown. It was believed that it could be congenital, but this has not yet been proven. A previous trauma could also be an important etiology to consider [77]. The typical presentation is given by the presence of a hard, painless mass that slowly increases in size under an overlying intact skin. Sometimes they are associated with headache, which can be of high intensity when the hemangioma expands [79]. The most common clinical feature is a solid tumor in the skull, painful or painless.

The cranial CT with a bone window is the diagnostic modality of choice, since it surpasses the sensitivity of simple radiography and allows bone to be defined in a superior way to MRI, giving a detailed image of the cortical and trabecular bone. Although the appearance in the CT can vary, the characteristic image consists of a 

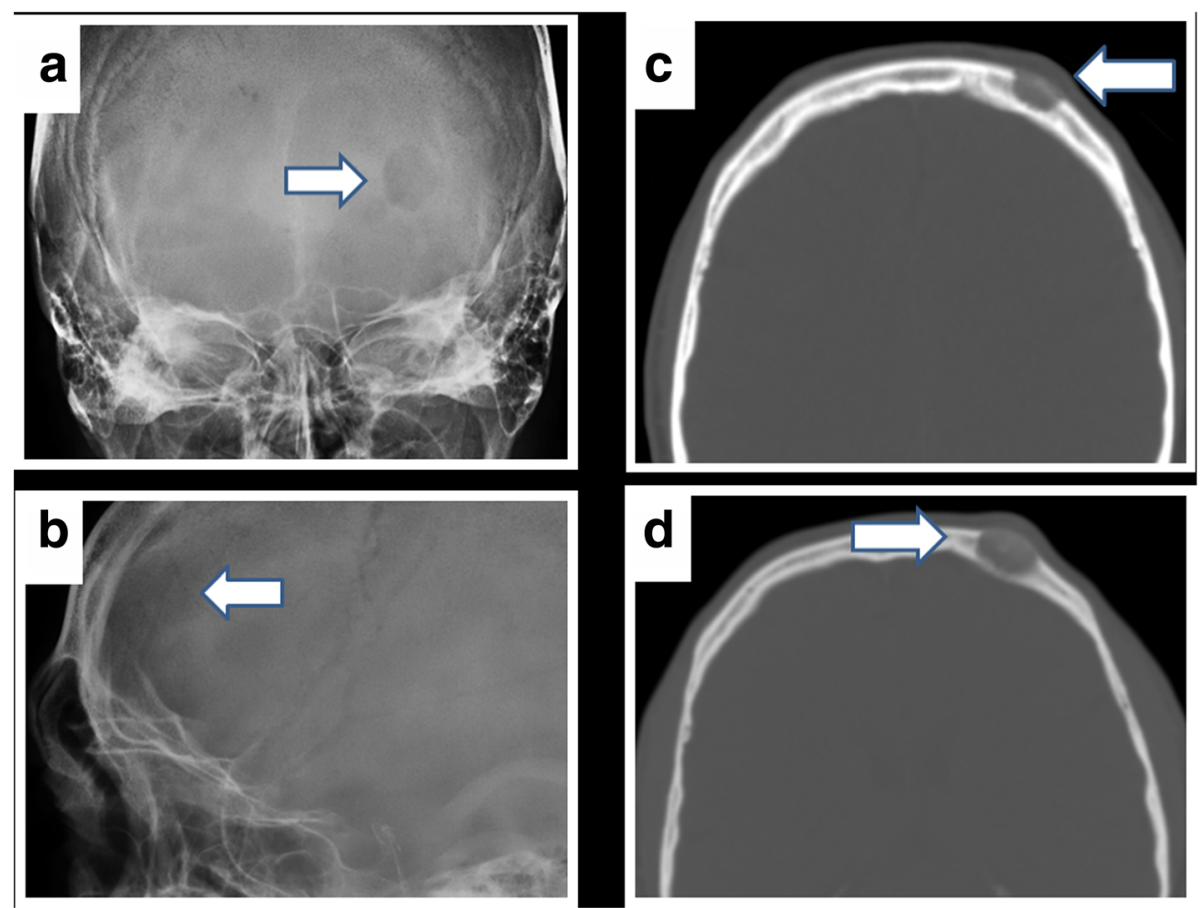

Fig. 1 Radiological images of a left frontal intraosseous lesion. a Simple X-ray of the skull, in the antero-posterior view and $\mathbf{b}$ in the lateral view of a radiolucent lesion (white arrows), rounded, with well-defined edges, located in the left frontal bone. c First CT cerebral with bone window performed on the patient 3 years ago. In localization of the left frontal region, a lytic bone lesion is observed that discreetly expands the diploe both in its internal and external table, with well-defined contours in its medullar region, being worse defined there could even be minimal solutions of continuity in the internal table. A poorly defined trabecular bone pattern was observed inside the lesion. The findings are compatible with a moderate aggressiveness. $\mathbf{d}$ In the last CT cerebral, it was appreciated how the lesion had increased in size. Produces a slight insufflation of the frontal calotte with loss of the cortex of the external table. Its behavior is of low radiological aggressiveness

lytic lesion, oval or rounded, expansive, and well delimited, with trabeculae that radiate from a common center in its interior in the tangential cuts, giving sometimes an appearance of honeycombing in the axial cuts [21]. It frequently invades and expands the external table, respecting the periosteum. Usually no signs of reactive hyperostosis are identified at their margins [22]. The cortex can undergo a great expansion leaving a thin bone layer, but in almost all cases, the periosteum remains intact and usually without reactive sclerosis at the margins. The angiography of these lesions, typically the largest, demonstrates a hypervascular lesion, but without drainage veins. Preoperative embolization may be useful in some cases [80]. The differential diagnosis includes other slow-growing, expanding bone lesions, such as osteoma, aneurysmal bone cyst, giant cell tumor, and multiple myeloma [81]. The radiological characteristics that help the differential diagnosis are shown in Table 2.

The natural history of these pathologies has not yet been described. Considering that osseous cavernous hemangiomas grow progressively, without spontaneous involution, their surgical treatment is usually recommended for several reasons: progression of the painful clinic, cosmetic implications, and, although with low frequency, avoidance of complications such as hemorrhages or nerve damage cranial, depending on the location of the lesion [22]. In 1923, Cushing designed the one that represents the treatment of choice of cranial cavernous hemangiomas to the present day: en bloc resection of the lesion, including a circumferential margin of the healthy bone [11]. On the other hand, the possibility of recurrence is avoided by including a margin of safety [77]. Most authors recommend total surgical excision to treat the mass effect and neurological compromise, to improve an esthetic deformity, and to obtain a definitive diagnosis [11]. The surgical approach becomes more difficult for those with extension to the base of the skull. Radiotherapy should be reserved for those lesions that are considered unresectable or in the case of recurrent tumors. This therapeutic modality stops tumor growth and reduces vascularization, but does not modify the size of the lesion and carries the risk of malignancy or the appearance of de novo malignancies [39]. 
Table 2 Differential diagnosis of skull vault lesions

\begin{tabular}{|c|c|c|c|}
\hline Lesion & Clinical features & Radiology & Treatment \\
\hline Osteoma & $\begin{array}{l}\text { Osteomas are slow-growing lesions that } \\
\text { are normally completely asymptomatic. } \\
\text { A few may be associated with Gardner } \\
\text { syndrome }\end{array}$ & $\begin{array}{l}\mathrm{CT} \text { : small, well-defined round, or oval dense } \\
\text { and homogeneous lesions; homogeneous } \\
\text { low signal intensity on T1Wl; variable } \\
\text { appearance on T2Wl; not enhance after } \\
\text { gadolinium administration }\end{array}$ & $\begin{array}{l}\text { Not require surgical treatment unless } \\
\text { the location or size of the lesion } \\
\text { affects the adjacent structures } \\
\text { (orbit, sinus, brain) }\end{array}$ \\
\hline $\begin{array}{l}\text { Aneurysmal } \\
\text { bone cyst }\end{array}$ & $\begin{array}{l}\text { Mainly in children and adolescents; may } \\
\text { be secondary to other underlying lesions } \\
\text { like fibrous dysplasia, chondroblastoma, } \\
\text { and osteosarcoma }\end{array}$ & $\begin{array}{l}\text { Sharply defined expanded osteolytic lesion } \\
\text { with thin sclerotic borders, although the } \\
\text { tables appear disrupted when the } \\
\text { expansion is significant }\end{array}$ & $\begin{array}{l}\text { The traditional treatment is complete } \\
\text { surgical excision }\end{array}$ \\
\hline Myeloma & $\begin{array}{l}\text { Bone pain, deterioration of health, or } \\
\text { abnormalities on blood or urinary test } \\
\text { (e.g., high erythrocyte sedimentation } \\
\text { rate, anemia) }\end{array}$ & $\begin{array}{l}\text { Multiple small, roundish osteolytic lesions } \\
\text { that are relatively uniform in size with } \\
\text { sharp and non-sclerotic margins. On MRI, } \\
\text { the signal intensity of the lesions is } \\
\text { nonspecific; a "salt and pepper" appearance } \\
\text { or diffuse bone marrow replacement } \\
\text { may be noted }\end{array}$ & $\begin{array}{l}\text { Treatment depends on the stage of the } \\
\text { disease. The most common treatments } \\
\text { are based on chemotherapy or grafting } \\
\text { of hematopoietic cells }\end{array}$ \\
\hline $\begin{array}{l}\text { Langerhans } \\
\text { histiocytosis }\end{array}$ & $\begin{array}{l}\text { Clinical features are variable, from } \\
\text { asymptomatic lesions to painful } \\
\text { swellings }\end{array}$ & $\begin{array}{l}\mathrm{CT} \text { : unequal involvement of the inner and } \\
\text { outer tables; appearance of having beveled } \\
\text { edges. The lesion center may contain a } \\
\text { sequestrum, representing residual intact } \\
\text { bone. MRI: usually strongly enhance after } \\
\text { gadolinium administration }\end{array}$ & $\begin{array}{l}\text { Single lesions: conservative treatment } \\
\text { (surveillance or systemic } \\
\text { corticosteroids). More diffuse or } \\
\text { aggressive forms: surgical excision, } \\
\text { radiotherapy, and chemotherapy }\end{array}$ \\
\hline Skull metastasis & $\begin{array}{l}\text { Usually secondary to the breast, lung, } \\
\text { prostate, kidney, and thyroid cancer; } \\
\text { generally asymptomatic; may be revealed } \\
\text { by a painful swelling }\end{array}$ & $\begin{array}{l}\text { Mostly multiple, well circumscribed } \\
\text { osteolytic lesions, which generally extend } \\
\text { into the adjacent soft tissues. Usually } \\
\text { homogeneously enhanced on enhanced } \\
\text { MRI, but heterogeneous enhancement, } \\
\text { peripheral ring enhancement, or lack of } \\
\text { enhancement (sclerotic lesions) can be } \\
\text { observed }\end{array}$ & $\begin{array}{l}\text { Surgical treatment may be possible } \\
\text { when there is only } 1 \text { metastasis, } \\
\text { especially if without any neoplastic } \\
\text { context. Radiotherapy is another } \\
\text { alternative }\end{array}$ \\
\hline $\begin{array}{l}\text { Intraosseous } \\
\text { meningioma }\end{array}$ & $\begin{array}{l}\text { Predominantly seen in women in the } \\
\text { fifth and sixth decades of life and } \\
\text { often revealed by painless and } \\
\text { expanded swelling }\end{array}$ & $\begin{array}{l}\text { CT: osteosclerotic lesion with destructive } \\
\text { irregular and spiculated borders. Low signal } \\
\text { intensity on T1Wl; variable signal intensity } \\
\text { on T2Wl; not enhance. Meningeal } \\
\text { enhancement is rare and is explained by } \\
\text { adjacent dural irritation or invasion, but the } \\
\text { center of the tumor growth is outside } \\
\text { the dura }\end{array}$ & $\begin{array}{l}\text { Surgical resection of the lesion is } \\
\text { required. The therapeutic decision } \\
\text { depends on the possibility of resecting } \\
\text { the lesion and on the patient's health }\end{array}$ \\
\hline $\begin{array}{l}\text { Epidermoid } \\
\text { and dermoid } \\
\text { cyst }\end{array}$ & $\begin{array}{l}\text { Painless subcutaneous swelling; } \\
\text { discovered mainly during the third and } \\
\text { fourth decades; predominantly occur } \\
\text { laterally in the parietal or frontal bone }\end{array}$ & $\begin{array}{l}\text { CT: well-demarcated osteolytic lesions with } \\
\text { sclerotic borders; may tend to expand into } \\
\text { both the inner and outer tables; } \\
\text { homogeneously hypodense. MRI: fluid-like } \\
\text { signal intensity on T1WI and T2WI and high } \\
\text { signal intensity on DWl; usually do not enhance }\end{array}$ & $\begin{array}{l}\text { Treatment of these cystic lesions is } \\
\text { surgical, usually without recurrence }\end{array}$ \\
\hline
\end{tabular}

This table shows the main clinical and radiological characteristics of possible differential diagnoses

\section{Conclusions}

Cranial cavernous hemangiomas are bony tumors of nature, which, in the absence of typical radiological features, are usually surgically treated under suspicion of another type of bone neoplasm. The treatment of choice is a complete resection by craniectomy, including healthy bone margins of safety, with good prognosis and little recurrence. In the presence of subtotal resections or progression, radiotherapy could be a valid option.

\section{Abbreviations}

CT: Computed tomography; DWl: Diffusion-weighted imaging; MRI: Magnetic resonance imaging; PICHs: Primary intraosseous cavernous hemangiomas;

T1Wl: T1-weighted imaging; T2Wl: T2-weighted imaging
Availability of data and materials

Please contact the author for data requests.

\section{Authors' contributions}

The individual contributions of authors to the manuscript are the following: AAS has made the elaboration of the manuscript, the description of the clinical case, the review of the literature and the surgery of the presented case. NFP has made the elaboration of the images and the table. MPS has made the revision of the manuscript. All authors read and approved the final manuscript.

Ethics approval and consent to participate Not applicable.

\section{Consent for publication}

Written informed consent for publication of their clinical details and/or clinical images was obtained from the patient/parent/guardian/relative of the patient. 


\section{Competing interests}

The authors declare that they have no competing interests.

\section{Publisher's Note}

Springer Nature remains neutral with regard to jurisdictional claims in published maps and institutional affiliations.

\section{Received: 11 March 2018 Accepted: 20 September 2018}

\section{Published online: 08 November 2018}

\section{References}

1. Park BH, Hwang E, Kim CH. Primary intraosseous hemangioma in the frontal bone. Arch Plast Surg. 2013;40:283-5.

2. Peterson DL, Murk SE, Story JL. Multifocal cavernous hemangioma of the skull: report of a case and review of the literature. Neurosurgery. 1992;30: 778-81

3. Pilcher LS. Venous tumour of the diploe: Trans Am Surg Assoc. 1894;2:2835 .

4. Wyke DB. Primary hemangioma of the skull: a rare cranial tumor. Am J Roentgenol. 1949;61:302-16.

5. Gupta SD, Tiwari IN, Pasupathy NK. Cavernous haemangioma of the frontal bone: case report. Br J Surg. 1975;62:330-2.

6. McIntyre NG, Brebner DM, Gluckman J. The cavernous haemangioma of the frontal bone. A case report. S Afr Med J. 1977:52:537-8

7. Gross HJ, Roth AM. Intraosseous hemangioma of the orbital roof. Am J Ophthalmol. 1978:86:565-9.

8. Fouad HA, Khalifa MC. Haemangioma of the frontal bone. J Laryngol Otol. 1979:93:513-8.

9. Shinno K, Nakagawa Y, Matsumoto K, li K. Cavernous hemangioma of the frontal bone. No Shinkei Geka. 1986;14:1231-5.

10. Hook SR, Font RL, McCrary JA, Harper RL. Intraosseous capillary hemangioma of the frontal bone. Am J Ophthalmol. 1987;103:824-7.

11. Zucker JJ, Levine MR, Chu A. Primary intraosseous hemangioma of the orbit: report of a case and review of the literature. Ophtalmic Plast Reconstr Surg. 1989:5:247-55

12. Hoffmann DF, Israel J. Intraosseous frontal hemangioma. Head Neck. 1990; 12:160-3.

13. Hornig GW, Beatty RM. Osteolytic skull lesions secondary to trauma. Report of two cases. J Neurosurg. 1990;72:506-8.

14. Sinnreich Z, Kremer S, Sade J, Bernheim J. Cavernous hemangioma of the frontal bone. ORL J Otorhinolaryngol Relat Spec. 1990;52:269-72.

15. Aurora A, Krishnan MM, Bahadur R, Vidyasagar JV, Ratnakar C. Cavernous hemangioma of the frontal bone: a case report. Indian J Ophthalmol. 1991; 39:76-7.

16. Faerber $T H$, Hiatt WR. Hemangioma of the frontal bone: review of the literature and report of a case. J Oral Maxillofac Surg. 1991:49:1018-22.

17. Relf SJ, Bartley GB, Unni KK. Primary orbital intraosseous hemangioma. Ophthalmology. 1991;98:541-7.

18. Cervoni L, Artico M, Delfini R. Intraosseous cavernous hemangioma of the skull. Neurosurg Rev. 1995;18:61-4.

19. Pastore FS, De Caro GM, Faiola A, Mauriello A, Giuffre R. Cavernous hemangioma of the parietal bone. Case report and review of the literature. Neurochirurgie. 1999:45:312-5.

20. Sharma RR, Pawar SJ, Lad SD, Netalkar AS, Musa MM. Frontal intraosseous cryptic hemangioma presenting with supraorbital neuralgia. Clin Neurol Neurosurg. 1999;101:215-9.

21. Suzuki Y, Ikeda H, Mutsamoto K. Neuroradiological features of intraosseous cavernous hemangioma. Neurol Med Chir (Tokyo). 2001;41:279-82.

22. Heckl S, Aschoff A, Kunze S. Cavernomas of the skull: review of the literature 1975-2000. Neurosurg Rev. 2002;25:56-62.

23. Pottelbergh R, Calenbergh F, Goffin J, Sciot R, Plets C. Tijdschrift voor Geneeskunde. 2004;60(2):126-31.

24. Politi M, Romeike BF, Papanagiotou P, Nabhan A, Struffert T, Feiden W, et al. Intraosseous hemangioma of the skull with dural tail sign: radiologic features with pathologic correlation. AJNR Am J Neuroradiol. 2005:26:2049-52.

25. Cheng NC, Lai DM, Hsie MH, Liao SL, Chen YB. Intraosseous hemangiomas of the facial bone. Plast Reconstr Surg. 2006;117:2366-72.

26. Buhl R, Barth H, Dörner L, Nabavi A, Rohr A, Mehdorn HM. De novo development of intraosseous cavernous hemangioma. J Clin Neurosci. 2007; 14:289-92.
27. Nasser K, Hayashi N, Kurosaki K, Hasegawa S, Kurimoto M, Mohammed A, et al. Intraosseous cavernous hemangioma of the frontal bone. Neurol Med Chir (Tokyo). 2007;47:506-8.

28. Naama O, Gazzaz M, Akhaddar A, Belhachmi A, Asri A. El- mostarchid B, et al. Cavernous hemangioma of the skull: 3 case reports. Surg Neurol. 2008; 70:654-9.

29. Sasagawa Y, Akai T, Yamamoto K, Masuoka T, Itou S, Oohashi M, et al. Multiple cavernous hemangiomas of the skull associated with hepatic lesions. Case report. Neurol Med Chir (Tokyo). 2009;49:162-6.

30. Carrasco-Moro R, García-Navarrete E, Navas-García M. M. Adrados de Llano y R. García de Sola Carrasco. Cavernous haemangioma of the skull. Neurocirugia (Astur). 2009;20(6):559-62.

31. Haeren RHL, Dings J, Hoeberigs MC, Riedl RG, Rijkers K. Posttraumatic skull hemangioma. Case report. Journal of Neurosurgery. 2012;6:1082-8.

32. Xu P, Lan S, Liang Y, Xiao Q. Multiple cavernous hemangiomas of the skull with dural tail sign: a case report and literatura review. BMC Neurol. 2013;13:155

33. Uemura K, Takahashi S, Sonobe M, Oyama K, Akai T, Sugita K. Intradiploic haemagioma o associated with epidural haematoma. Neuroradiology. 2014; 38:456-7.

34. Murrone D, De Paulis D, Millimaggi DF, Del Maestro M, Galzio RJ. Cavernous hemangioma of the frontal bone: a case report. J Med Case Rep. 2014;8:121.

35. Chun KA, Kong E, Cho I. An Incidental Finding of Skull Hemangioma During 18F-FP CIT Brain PET/CT. Clin Nucl Med. 2015;40(10):e488-9. https://doi.org/ 10.1097/RLU.0000000000000907.

36. Hsiao IH, Cho DY, Liu CL. Multifocal osteolytic lesions of the skull: a primary cavernous hemangioma mimicking a neoplastic invasive lesion. Biomedicine (Taipei). 2015:5:12.

37. Y Yang, J Guan, Ma W, et al. Primary Intraosseous Cavernous Hemangioma in the Skull. Medicine (Baltimore). 2016. https://doi.org/10.1097/MD. 0000000000003069 .

38. Sargent EN, Reilly EB, Posnikoff J. Primary hemagioma of the skull. Case report of an unusual tumor. AM J Roentgenol Radium Ther Nucl Med. 1965;95:874-9

39. Mangham CA, Carberry JN, Brackmann DE. Management of intratemporal vascular tumors. Laryngoscope. 1981;91:867-6.

40. Glasscock MEIII, Smith PG, Schwaber MK, Nissen AJ. Clinical aspects of osseous hemangiomas of the skull base. Laryngoscope. 1984:94:869-73.

41. Suss RA, Kumar AJ, Dorfman HD, Miller NR, Rosenbaum AE. Capillary hemangioma of the sphenoid bone. Skeletal Radiol. 1984;11:102-7.

42. Mazzoni A, Pareschi R, Calabrese V. Intratemporal vascular tumours. J Laryngol Otol. 1988;102:353-6.

43. Buchanan DS, Fagan PA, Turner J. Cavernous hemangioma of the temporal bone. J Laryngol Otol. 1992;106:1086-8.

44. Fierek O, Laskawi R, Kunze E. Large intraosseous hemangioma of the temporal bone in a child. Ann Otol Rhinol Laryngol. 2004;113:394-8.

45. Silva RD, da Silva Cavalcante JE, Miranda EQ, Lopes DF, Souto LR. Giant hemangioma presenting as a scalp mass leading to a craniofacial deformity. J Maxillofac Oral Surg. 2013;12(2):218-23. https://doi.org/10.1007/s12663011-0218-9. Epub 2011 Apr 20.

46. Yang $\mathrm{M}$, Yan JJ. Long term surgical outcomes of orbital cavernous haemangiomas (low-flow venous malformations) as performed in a tertiary eye hospital in China. Craniomaxillofac Surg. 2014 Oct:42(7):1491-6.

47. Yetişer $\mathrm{S}$, Yapıcıer O. Primary intraoseous hemangioma of temporal bone. Kulak Burun Bogaz Ihtis Derg. 2014;24(2):100-4. https://doi.org/10.5606/ kbbihtisas.2014.45452

48. Corr P. Multiple calvarial haemangiomas. Australas Radiol. 2000;44:118-20.

49. García-Marín V, Ravina J, Trujillo E, González-Feria L. Symptomatic cavernous hemangioma of the occipital condyle treated with methacrylate embolization. Surg Neurol. 2001:56:301-3.

50. Khanam H, Lipper MH, Wolff CL, Lopes MB. Calvarial hemangiomas: report of two cases and review of the literature. Surg Neurol. 2001:55:63-7.

51. Gibson SE, Prayson RA. Primary skull lesions in the pediatric population: a 25-year experience. Arch Pathol Lab Med. 2007;131:761-6.

52. Reis BL, Carvalho GT, de Sousa AA, de Freitas WB, Castro Santiago Brandão RA. Primary hemangioma of the skull Arq. Neuro-Psiquiatr. 2008;66:3.

53. Nair P, Srivastava AK, Kumar R, Jain K, Sahu RN, Vij M, Jain M. Giant primary intraosseous calvarial hemangioma of the occipital bone. Neurol India. 2011; 59(5):775-6. https://doi.org/10.4103/0028-3886.86568.

54. Toynbee J. An account of two vascular tumors developed in the substance of bone. Lancet. 1845;2:676. 
55. Kumar S, Gupta S, Puri V, Mehndiratta MM, Malhotra V. Intradiploic hemangioma of skull bone. Indian Pediatr. 1993;30:399-401.

56. Yoshida D, Sugisaki Y, Shimura T, Teramoto A. Cavernous hemangioma of the skull in a neonate. Childs Nerv Syst. 1999:15:351-3.

57. Ajja A, Oukacha N, Gazzaz M, Akhaddar A, Elmostarchid B, Kadiri B, et al. Cavernous hemangioma of the parietal bone. A case report. J Neurosurg Sci. 2005;49:159-62.

58. Paradowski B, Zub W, Sasiadek M, et al. Intraosseous hemangioma in parietal bone. Neurology. 2007;68:44.

59. Rumana M, Khursheed N, Farhat M, et al. Congenital intraosseous cavernous hemangioma of the skull: an unusual case. Pediatr Neurosurg. 2013;49:229-31.

60. Atci IB, Albayrak S, Yilmaz N, et al. Cavernous hemangioma of the parietal bone. Am J Case Rep. 2013;14:401-4.

61. Kilani M, Darmoul M, Hammedi F, et al. Cavernous hemangioma of the skull and meningioma: association or coincidence? Case Rep Neurol Med. 2015: 716-837.

62. Sarmast $A H$, Shafi $Y$, Kirmani $A R$, Bhat AR. A rare case of parietal bone hemangioma. J Neurosci Rural Pract. 2016;7(3):456-7. https://doi.org/10. 4103/0976-3147.181458.

63. Brichacek M, Naeem A, Filler G, Hammond R, Yazdani A, Ranger A Congenital Calvarial Hemangioma. J Craniofac Surg. 2018 May 8. https://doi. org/10.1097/SCS.0000000000004613.

64. Jackson CG, Glasscock MEIII, Hughes G, Sismanis A. Facial paralysis of neoplastic origin: diagnosis and management. Laryngoscope. 1980;90:1581-95.

65. Bottrill I, Poe DS. Diagnosis imaging quiz case 2. Arch Otolaryngol. 1995;121: 348-50.

66. Chatterhi P, Verma SM, Mathur JS. Haemangioma of the frontal bone. Journal of Laryngology and Otology. 1969;83:917.

67. Schofield AL. Primary haemangioma of the malar bone. Br. J. Plast. Surg. 1950;3:136-8.

68. Dickins J. Cavernous hemangioma of the sphenoid wing. Arch Otolaryngol. 1978;104:58-60.

69. Inoue A, Yamada K, Kishida K, Nakai O. Calvarial hemangioma. Report of two cases and study of 62 cases from the literature (author's transl). Neurol Med Chir (Tokyo). 1982;22:147-53.

70. Tashiro T, Inoue Y, Nemoto Y, Shakudo M, Mochizuki K, Katsuyama J, et al. Cavernous hemangioma of the clivus: case report and review of the literature. AJNR Am J Neuroradiol. 1991:12:1193-4.

71. Slaba SG, Karam RH, Nehme Jl, Nohra GK, Hachem KS, Salloum JW. Intraosseous orbitosphenoidal cavernous angioma. Case report. J Neurosurg. 1999;91:1034-6.

72. Moore SL, Chun JK, Mitre SA, Som PM. Intraosseous hemangioma of the zygoma: CT and MR findings. AJNR Am J Neuroradiol. 2001;22:1383-5.

73. Liu JK, Burger PC, Harnsberger HR, Couldwell WT. Primary intraosseous skull base cavernous hemangioma: case report. Skull Base. 2003;13:219-28.

74. Jeong WJ, Rhee CS. Primary intraosseous orbital hemangioma of the lacrimal bone. Jpn J Ophthalmol. 2006 Mar-Apr;50(2):189-90.

75. Salunke $P$, Sinha R, Khandelwal NK, et al. Primary intraosseus cavernous hemangioma of the skull base. Br J Neurosurg 2010; 24:84-5.

76. Moravan MJ, Petraglia AL, Almast J, et al. Intraosseous hemangiomas of the clivus: a case report and review of the literature. J Neurosurg Sci. 2012;56: 255-9.

77. Yu J, Li Y, Duan X. Posttraumatic cavernous hemangioma of the skull. J Craniofac Surg. 2017:25:e48-51.

78. Hernández-Borroto CE, Amado-Donestévez A, Vaquer-Fernández JE, Medrano-Plana Y, Ruíz-Martín M. Hemangioma cavernoso gigante de la bóveda craneal. Rev Neurol. 2004;38:799-800.

79. Bucy PC, Capp CS. Primary hemangioma of bone with special reference to roentgenologic diagnosis. AJR Am J Roentgenol. 1930;23:1-33.

80. Lobato RD, Lamas E, Amor T, Rivas JJ. Primary calvarial hemangioma: angiographic study. Surg Neurol. 1978;10:389-94.

81. Patnaik A, Mishra SS, Mishra S, et al. Intradiploic ossified giant cavernous hemangioma of skull with a dural tail sign mimicking primary calvarial meningioma. Neurol India. 2012;60:250-2.

\section{Submit your manuscript to a SpringerOpen ${ }^{\circ}$ journal and benefit from:}

- Convenient online submission

- Rigorous peer review

- Open access: articles freely available online

- High visibility within the field

- Retaining the copyright to your article

Submit your next manuscript at $\boldsymbol{\nabla}$ springeropen.com 